\title{
Role of biochar on soil fertility improvement and greenhouse gases sequestration
}

\begin{abstract}
Biochar is mostly porous, stable $\mathrm{C}$ rich, formed at high temperature, highly serpent and nutrient rich material. The objective of this work was to understand the role of biochar on soil fertility improvement and greenhouse gases sequestration. Biochar application can improve soil fertility by manipulating soil properties that is soil porosity, soil water holding capacity, soil aggregation soil reaction $(\mathrm{pH})$, soil organic carbon these soil physicochemical properties improved and the soil becomes safe nutrient rich to support plant growth. In addition biochar application increases the activities and population rhizobia species in the soil. Emissions of greenhouse gases were suppressed by application of biochar in agricultural fields. Soil contaminant effectively adsorbed, suppressed biodegradation and leaching of contaminants in to ground water. The efficiency of biochar's depends on feedstock type, pyrolysis temperature. Biochar is the most eco-friendly technology that should be used for soil fertility improvement and reduced the emission of greenhouse gases.
\end{abstract}

Keywords: Biochar, soil fertility, greenhouse gases emission, remediation

Volume 3 Issue 6 - 2019

Dereje Dejene,' Eyob Tilahun²

'Department of Natural Resource Management, Wolkite University, Ethiopia

${ }^{2}$ Department of Natural Resource Management, Debre Tabor University, Ethiopia

Correspondence: Dereje Dejene, Department of Natural Resource Management,Wolkite University, Ethiopia Tel +251912307790, Email dereje.dejne@wku.edu.et, aadre2008@gmail.com

Received: October 22, 2019 | Published: December II, 2019

\section{Introduction}

Soil fertility decline and greenhouse gase emission has been perceived as widespread treating challenges in the world. ${ }^{1}$ According to Jones et al. ${ }^{2}$ crop production shared about 10 to $12 \%$ of global greenhouse gases (GHG) emissions and land conversion from forest and pasture to croplands, soil and biomass carbon that accounts an additional 12 to $20 \%$ of global GHG emissions and to overcome these bottlenecks, Bichar amendment has been recognized as best method.

International Biochar Initiative (IBI) defined biochar as "a solid material obtained from the thermo-chemical conversion of biomass in an oxygen-limited environment". ${ }^{3}$ Others also defined it as a carbon-rich and mostly alkaline material produced by thermochemical conversion of organic materials such as agricultural residues and municipal wastes in a controlled low-oxygen environment. ${ }^{4}$ Following, Paris agreement on climate change mitigation held in December 2015, many countries have been paid attention in biochar application due to different benefits. Even some countries have been forced their people not to burn residual materials in open field. For example, in China, straw burning in open field was strictly forbidden according to the state calls for alternative treatments of waste as raw material for biochar. ${ }^{5}$

Addition of biochar to soil showed increased plant growth and crop yield, improved soil properties, ${ }^{7}$ enhanced the bioavailability of nutrients, improved stress tolerance of plants to salinity, drought, heavy metal toxicity and high temperature ${ }^{8}$ and also decreased soil nutrients leaching. ${ }^{9}$ Biochar has also received increasing attention due to its ability to mitigate climate change ${ }^{10}$ due to high carbon sequestration capacity. ${ }^{11}$ Basically, amendment of biochar reduced emission of soil nitrous oxide $\left(\mathrm{N}_{2} \mathrm{O}\right)$, methane $\left(\mathrm{CH}_{4}\right){ }^{12}$ and had capable of offsetting about $12 \%$ of anthropogenic $\mathrm{CO}_{2}-\mathrm{C}$ emission. ${ }^{13} \mathrm{In}$ addition to this, biochar has been suggested as one of the most eco-friendly and promising approach to reduce environmental contaminants. ${ }^{14}$

\section{Objective}

\section{General objective}

The general objective of this review was to understand role of biochar on soil fertility improvement and greenhouse gases sequestration

\section{Specific objectives}

Based on the general objective mentioned above, the following specific objectives were stated as.

i. To recognize the role of biochar in soil fertility improvement and

ii. To recognize the role of biochar in greenhouse gases sequestration and gaps

\section{Significance of the review}

Presence of different research findings about the role of biochar in soil fertility improvement and greenhouse gases sequestration were known at large but most of these findings were scattered. So, this reviewed document will help readers to accesses compiled data.

\section{Scope of the review}

As much as possible, the review was focused at findings and reports that have done around the globe about the role of biochar in soil fertility and greenhouse gases sequestration.

\section{Methodology}

Published articles (62 article with peer reviewed, 3 article with single author), 1 organizational report, 1 in-press paper, totally 67 references were used. An as much as possible, latest article which contains quantitative data were searched in Google Scholar and purposively selected. Endnote software was used for citation in the text and end reference by using APA style of referencing with synchronization of it with seminar wring guideline of CDAN of Mekelle university.

\section{Review of literature and discussion}

\section{Characteristics of biochar}

Biochar is carbon-rich, ${ }^{15}$ and has high chemical and biological stability. ${ }^{16}$ Usually, biochar has high porosity, large specific surface area, adsorption ability, and high cation exchange capacity. ${ }^{17}$ The 
elemental composition of biochar usually includes higher proportion of C. ${ }^{15}$ The characteristic of biochar depends by feedstock type and pyrolysis temperature ${ }^{18}$ as indicated from the (Table 1) (Figure 1).

\section{The role of biochar in soil fertility}

\section{Effects of biochar on soil properties}

Soil porosity: Hseu et al. ${ }^{19}$ reported that amending of rice husk biochar to soil increased the abundance of macro-pores and micropores from 4 to $27 \%$ and 11 to $54 \%$, respectively. Similarly, Gamage et al. ${ }^{20}$ reported that the application of rice husk biochar significantly increased the porosity of clayey textured soils. These increased results could be attributed to soil particle rearrangement due to biochar application.

Soil water holding capacity: Soil moisture content of wood-land increased from 6 to $25 \%$ after the application of green waste biochar at the rate of $20 \mathrm{t} \mathrm{ha}^{-1} \cdot{ }^{21}$ Similarly, Li et al. ${ }^{22}$ reported that overall average runoff decreased by $28 \%$ after the application of rice straw biochar at a rate of $20 \mathrm{t} \mathrm{ha}^{-1}$ over the period of 2 years when compared to that of a control treatment. The reduction in runoff was attributed to the strong water retention effect of biochar. Uzoma et al. ${ }^{23}$ found that sandy soils with biochar amendment showed increase in water holding capacity from 0.2 to $56.1 \%$. Dan et al. ${ }^{24}$ also confirmed that treatment of soil with biochar significantly increased the water holding capacity of sandy soils.

Soil aggregation: Application of biochar has shown positive effect on soil aggregation. ${ }^{25}$ Zhang ${ }^{26}$ also reported that addition of biochar in a loamy soil significantly promoted the formation and stabilization of macro-aggregates. Likewise, Lu et al. ${ }^{25}$ observed that addition of rice husk biochar increased soil aggregation more than three times that of original pore space (from 8 to $36 \%$ ) in Vertisol. Similarly, Ouyang et al..$^{27}$ revealed that the amending of dairy manure biochar to the soil significantly promoted the formation of aggregates in both silty-clay and sandy-loam textured soils.

Table I Characteristics of biochar produced from different feedstock and pyrolysis temperature

\begin{tabular}{|c|c|c|c|c|c|c|c|}
\hline Feedstock Type & Pyrolysis $\mathrm{T}^{\circ}$ & pH & C (\%) & $\begin{array}{l}\text { P.V }\left(\mathbf{c m}^{3}\right. \\
\left.\mathrm{g}^{-1}\right)\end{array}$ & $\begin{array}{l}\text { S.A }\left(m^{2}\right. \\
\left.g^{-1}\right)\end{array}$ & $\begin{array}{l}\text { CEC (Cmol } \\
\left.\mathrm{kg}^{-1}\right)\end{array}$ & References \\
\hline Feed lot & 350 & 9.1 & 53 & & & - & Cantrell et al. ${ }^{68}$ \\
\hline Feed lot & 700 & 10.3 & 52 & & & - & Cantrell et al. ${ }^{68}$ \\
\hline Soybean & 300 & 7.3 & 69 & - & 5.6 & - & Ahmad et al..$^{14}$ \\
\hline Soybean & 700 & 11.3 & 82 & 0.2 & 420 & - & Ahmad et al..$^{14}$ \\
\hline Turkey litter & 350 & 8 & 49 & - & 2.6 & - & Cantrell et al. ${ }^{68}$ \\
\hline Turkey litter & 700 & 10 & 45 & - & 66 & - & Cantrell et al. ${ }^{68}$ \\
\hline Tire rubber & 200 & - & 75 & - & - & - & Lian et al. ${ }^{.2}$ \\
\hline Tire rubber & 400 & - & 78 & 0.08 & - & - & Lian et al. ${ }^{.2}$ \\
\hline Tire rubber & 600 & - & 81 & 0.12 & & - & Lian et al. ${ }^{52}$ \\
\hline Tire rubber & 800 & - & 86 & 0.11 & & - & Lian et al. ${ }^{52}$ \\
\hline Eucalyptus & 700 & 6 & 37 & - & - & 129.75 & Eyob and Dereje, in press \\
\hline Acacia & 700 & 8.1 & 66 & - & - & 117.00 & Eyob and Dereje, in press \\
\hline FYM & 700 & 8.2 & 23 & - & - & 87.25 & Eyob and Dereje, in press \\
\hline Rice straw & 700 & 6.4 & 41 & - & - & 127.50 & Eyob and Dereje, in press \\
\hline
\end{tabular}

Where: PV pore volume and SA surface area

Soil pH: Increased soil $\mathrm{pH}$ as a result of biochar application has been extensively investigated in agricultural soils ${ }^{15}$ and Rhoades et al..$^{28}$ also reported that the combined application of biochar with rate of $\left(20\right.$ tha $\left.^{-1}\right)$ and mulch $\left(37 \mathrm{t} \mathrm{ha}^{-1}\right)$ increased soil $\mathrm{pH}$ from 5.7 to 6.4 in forest soil.

The observed increase in soil $\mathrm{pH}$ may be simply due to the addition of alkaline material ${ }^{29}$ or biochar application decreases the exchangeable aluminum content of soils through binding $\mathrm{Al}^{3+}$ ion by oxygenated functional groups on its surface, thereby increasing the abundance of soil exchangeable base cations that ultimately resulting in a soil $\mathrm{pH}$ increase. ${ }^{30}$ So, biochar has been used as an excellent alternative amendment of acidic soil reclamation to increase soil $\mathrm{pH} .{ }^{30}$ However, some studies have shown no effect of biochar application on $\mathrm{pH}$ of forest soils. ${ }^{31}$ These contradicting findings among different studies may be attributed due to differences in biochar feedstock, the pyrolysis process, and diverse soil properties.
Soil organic carbon: Concentration of soil organic carbon content showed increase after addition of biochar as reported by Laird et al..$^{32}$ Wang et al. ${ }^{33}$ also reported that addition of biochar at the rate of (5 tha$\left.{ }^{1}\right)$ significantly increased soil organic carbon content. Primary reason for these observations could be due to presence of stable carbon in the biochar that is difficult to decompose in soil environments, thus contributing to the soil carbon pool. ${ }^{34}$

Biochar as nutrients source and bio-availability: Biochar application increases nutrients content and bioavailability for plants since biochar itself contains various nutrients. ${ }^{35}$ Biochar produced from wood waste materials generally contains high levels of soluble $\mathrm{K}$ and variable concentrations of $\mathrm{P}$ and $\mathrm{Ca}^{36}$

Sackett et al. ${ }^{31}$ observed that bio-available $\mathrm{K}, \mathrm{Ca}$ and $\mathrm{Mg}$ concentrations significantly increased after biochar application at a rate of $\left(5\right.$ tha $\left.^{-1}\right)$. In addition, Gundale et al. ${ }^{37}$ reported that biochar addition at a rate of $\left(10\right.$ tha $\left.^{-1}\right)$ increased the soil's net $\mathrm{N}$ mineralization 
rate and $\mathrm{NH}^{+}$concentration. Other studies also have shown that biochar application increased other nutrient concentrations including silica and boron. ${ }^{38}$

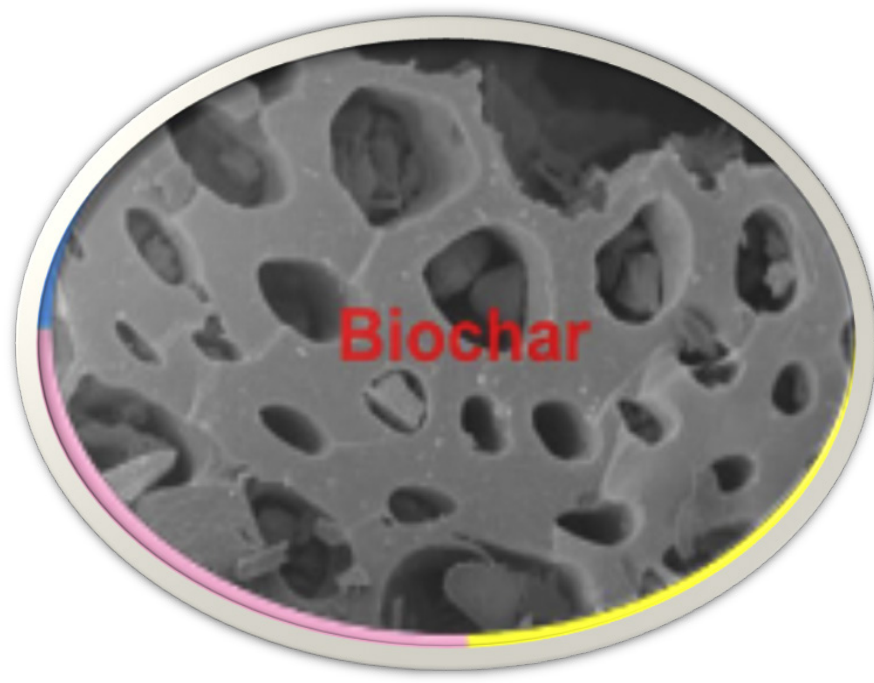

Figure I Diagrammatic presentation of porous nature of biochar (source: $\mathrm{Li}$ et al., 2017)

Lehmann et al. ${ }^{39}$ pointed that the immediate beneficial effects of biochar application on plant growth and yield in tropical soils can be attributed to the increased concentration of $\mathrm{Ca}, \mathrm{Cu}, \mathrm{K}, \mathrm{P}$, and $\mathrm{Zn}$.
However, the effect of biochar application on plant growth and yield over the long term was mainly due to modifying nutrient bioavailability rather than via the direct supply of nutrients from biochar (Figure 2). ${ }^{40}$

Biochar based microbs: It has been reported that population of rhizobia associated with chickpea was higher in biochare amended soil due to suitability of biochar as carrier of microbes. ${ }^{41}$ Saranya et al. ${ }^{42}$ reported that applying biochar with Azospirillum significantly increased the rhizosphere population of Azospirillum and other diazotrophic microorganisms.

In addition, biochar-based microbes promoted plant growth and nutrient uptake. ${ }^{43}$ The biochar-based seed coating with microbes also improved germination, root and shoot growth, chlorophyll content, and phosphorous uptake of plants. ${ }^{44}$ Nodule number of lupine plants where seeds were treated with biochar based microbes was increased by up to $146 \%$ under drought stress conditions compared to none biochare based..$^{45}$ Generally, due to porous nature of biochar, microbes living inside pores may get better protected from external factors such as drought, adverse $\mathrm{pH}$, or toxic substances in soil. ${ }^{46}$

\section{Effects of biochar on greenhouse gases emission}

Soil $\mathrm{co}_{2}$ emission: Most of recent findings reported that soil treated with biochar decreased $\mathrm{CO}_{2}$ emission or no effect. Sun et al ${ }^{47}$ found that application of biochar with rate of 30 tha $^{-1}$ significantly reduced $\mathrm{CO}_{2}$ emissions by $31.5 \%$ in forest soil. But, Sackett et al. ${ }^{31}$ and Zhou et al. ${ }^{48}$ found that biochar application did not affect the $\mathrm{CO}_{2}$ emissions as indicated in (Table 2).

Table 2 Effect of biochar application the green house gases emission in forest soils

\begin{tabular}{|c|c|c|c|c|c|c|c|}
\hline Soil type & Biochar type & $\begin{array}{l}\text { Biochar } \\
\text { rate }\end{array}$ & $\begin{array}{l}\text { Time } \\
\text { (duration) }\end{array}$ & $\mathrm{CO}_{2}$ emission & $\mathrm{CH}_{4}$ uptake & $\begin{array}{l}\mathrm{N}_{2} \mathrm{O} \\
\text { emission }\end{array}$ & References \\
\hline Cambisols & $\begin{array}{l}\text { Corn silage } \\
\left(500^{\circ} \mathrm{C}\right)\end{array}$ & I w/w & 105 days & Not significant & Not significant & Decreased & $\begin{array}{l}\text { Malghani et } \\
\text { al. } .^{56}\end{array}$ \\
\hline Ferralsols & $\begin{array}{l}\text { Chicken } \\
\text { manure }(540 \\
\left.{ }^{\circ} \mathrm{C}\right)\end{array}$ & $10 \%, w / w$ & 84 days & - & $\begin{array}{l}\text { Significantly } \\
\text { Increased }\end{array}$ & - & Yyu. \\
\hline Brunisol & $\begin{array}{l}\text { Sugar maple } \\
\text { wood }(500 \\
\left.{ }^{\circ} \mathrm{C}\right)\end{array}$ & $\begin{array}{l}5,10, \& 20 \\
t \text { ha }^{-1}\end{array}$ & 24 days & $\begin{array}{l}\text { Significantly } \\
\text { increased }\end{array}$ & - & - & Mitchell et al. ${ }^{49}$ \\
\hline $\begin{array}{l}\text { Humo-ferric } \\
\text { Podzols }\end{array}$ & $\begin{array}{l}\text { Douglas-fir } \\
\left(420^{\circ} \mathrm{C}\right)\end{array}$ & $\mathrm{I} \%, w / w$ & 25 days & $\begin{array}{l}\text { Significantly } \\
\text { increased }\end{array}$ & $\begin{array}{l}\text { Significantly } \\
\text { decreased }\end{array}$ & Not significant & $\begin{array}{l}\text { Hawthorne } \\
\text { et al. }{ }^{58}\end{array}$ \\
\hline $\begin{array}{l}\text { Humo-ferric } \\
\text { Podzols }\end{array}$ & $\begin{array}{l}\text { Douglas-fir } \\
\left(420^{\circ} \mathrm{C}\right)\end{array}$ & $10 \%, w / w$ & 25 days & $\begin{array}{l}\text { Significantly } \\
\text { increased }\end{array}$ & $\begin{array}{l}\text { Significantly } \\
\text { decreased }\end{array}$ & $\begin{array}{l}\text { Increased by } \\
191 \%\end{array}$ & $\begin{array}{l}\text { Hawthorne } \\
\text { et al. }{ }^{58}\end{array}$ \\
\hline Lixisol & $\begin{array}{l}\text { Wheat straw } \\
\left(450^{\circ} \mathrm{C}\right)\end{array}$ & $30 \mathrm{t} \mathrm{ha}^{-1}$ & I year & $\begin{array}{l}\text { Decreased by } \\
31.5 \%\end{array}$ & - & $\begin{array}{l}\text { D Decreased } \\
\text { by } 25.5 \%\end{array}$ & SSun et al..$^{25}$ \\
\hline Ferralsols & $\begin{array}{l}\text { Bamboo leaf } \\
\left(500^{\circ} \mathrm{C}\right)\end{array}$ & $5 \mathrm{t} \mathrm{ha}^{-1}$ & I year & Not significant & - & - & Wang et al. ${ }^{33}$ \\
\hline $\begin{array}{l}\text { Humo-ferric } \\
\text { Podzols }\end{array}$ & $\begin{array}{l}\text { Mixed maple } \\
\& \text { spruce } \\
\text { sawdust }(350- \\
\left.450^{\circ} \mathrm{C}\right)\end{array}$ & $5 \mathrm{tha}^{-1}$ & I year & Not significant & Not significant & Not significant & Sackett et al..$^{31}$ \\
\hline
\end{tabular}




\begin{tabular}{|c|c|c|c|c|c|c|c|}
\hline Soil type & Biochar type & $\begin{array}{l}\text { Biochar } \\
\text { rate }\end{array}$ & $\begin{array}{l}\text { Time } \\
\text { (duration) }\end{array}$ & $\mathrm{CO}_{2}$ emission & $\mathrm{CH}_{4}$ uptake & $\begin{array}{l}\mathbf{N}_{2} \mathbf{O} \\
\text { emission }\end{array}$ & References \\
\hline Ferralsols & $\begin{array}{l}\text { Bamboo leaf } \\
\left(500{ }^{\circ} \mathrm{C}\right)\end{array}$ & $5 \mathrm{tha}^{-1}$ & I year & - & - & $\begin{array}{l}\text { Decreased by } \\
20.5\end{array}$ & Xiao et al. ${ }^{54}$ \\
\hline $\begin{array}{l}\text { Humo-ferric } \\
\text { Podzols }\end{array}$ & $\begin{array}{l}\text { Douglas-fir } \\
\text { slash }\left(420^{\circ} \mathrm{C}\right)\end{array}$ & $20 \mathrm{t} \mathrm{ha}^{-1}$ & 3 months & $\begin{array}{l}\text { Increased by } \\
6.6 \%\end{array}$ & $\begin{array}{l}\text { Decreased by } \\
8.4\end{array}$ & - & Johnson et al..$^{50}$ \\
\hline Ultisol & $\begin{array}{l}\text { Chicken } \\
\text { manure (400 } \\
\left.{ }^{\circ} \mathrm{C}\right)\end{array}$ & $24 \mathrm{t} \mathrm{ha}^{-1}$ & I year & - & Not significant & Not significant & Lin et al. ${ }^{22}$ \\
\hline Ferralsols & $\begin{array}{l}\text { Bamboo (800 } \\
\left.{ }^{\circ} \mathrm{C}\right)\end{array}$ & $\begin{array}{l}10 \text { and } 30 \\
\mathrm{t} \mathrm{ha}^{-1}\end{array}$ & 16 months & Not significant & - & - & Zhou et al. ${ }^{48}$ \\
\hline Ferralsols & $\begin{array}{l}\text { Bamboo (800 } \\
\left.{ }^{\circ} \mathrm{C}\right)\end{array}$ & $\begin{array}{l}10 \text { and } 30 \\
\mathrm{tha}\end{array}$ & 16 months & Not significant & - & - & Zhou et al. ${ }^{48}$ \\
\hline
\end{tabular}

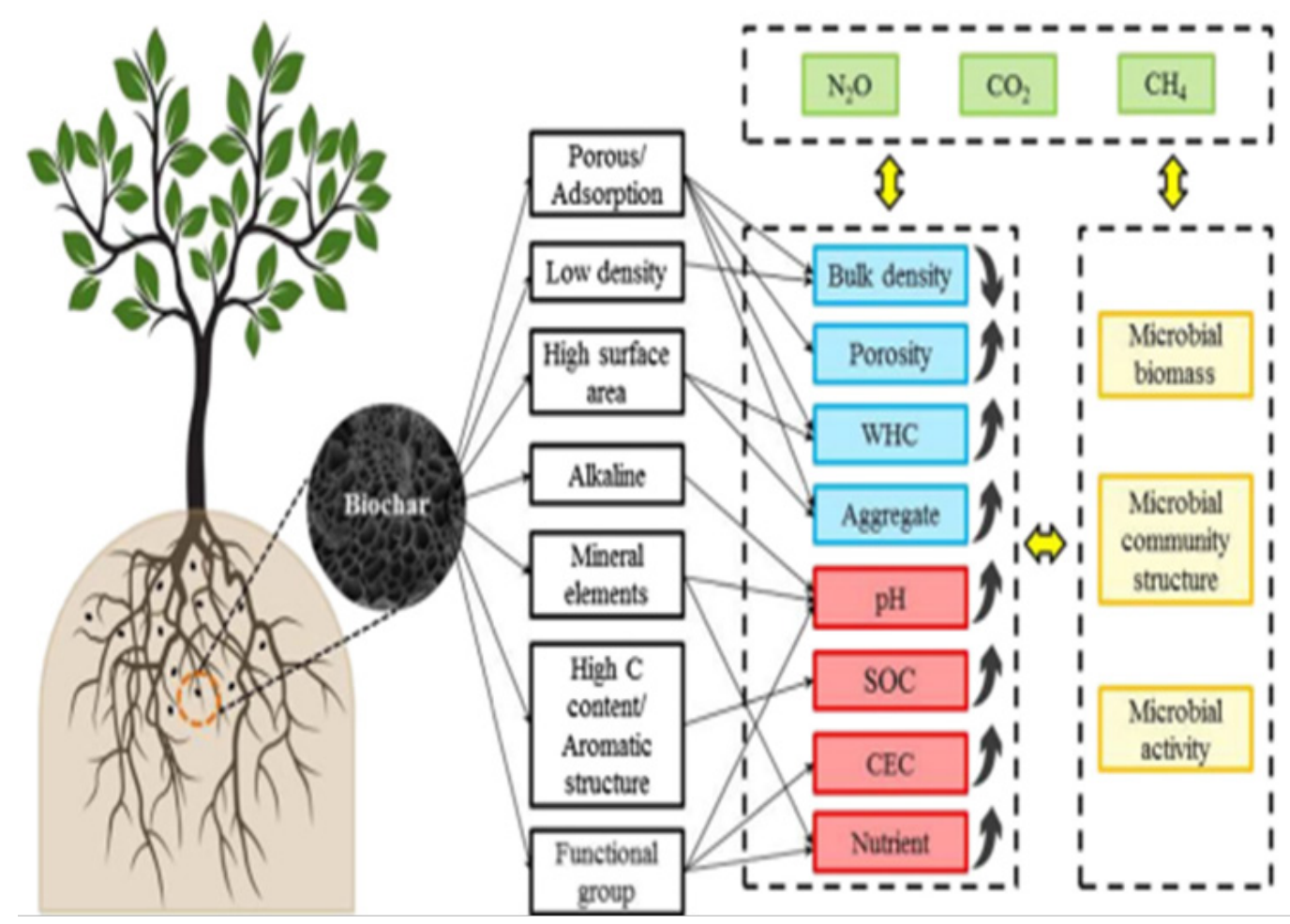

Figure 2 Conceptual framework for effects of biochar application on soil properties and green house gases emission.

On other hand, Mitchell et al. ${ }^{49}$ reported that the application of sugar maple biochar with rate of $\left(5,10\right.$, and $\left.20 \mathrm{t} \mathrm{ha}^{-1}\right)$ significantly increased soil $\mathrm{CO}_{2}$ emissions in a temperate forest soil. Similarly, Johnson et al. ${ }^{50}$ also reported increased $\mathrm{CO}_{2}$ emissions from a biocharamended soil compared to that of emissions from the untreated control soil (Table 2).

The variability of effects of biochar application on soil $\mathrm{CO}_{2}$ flux in the above studies might be due to differences in the type and rate of biochar applied, vegetation and soil types, in addition to the time period between $\mathrm{CO}_{2}$ measurement and biochar application. ${ }^{51}$

Soil $\mathbf{C H}_{4}$ emission: Addition of biochar suppressed $\mathrm{CH}_{4}$ emission especially from waterlogged rice paddy soil as reported by Liu et al. ${ }^{52}$ and also application of chicken manure biochar significantly decreased $\mathrm{CH}_{4}$ emission in forest soil. ${ }^{53}$ Biochar amendment significantly decreased soil $\mathrm{CH}_{4}$ emission in an intensively managed plantation regardless of the application rate. ${ }^{54}$ Amendment of biochar decreased soil bulk density and increased soil porosity which favors $\mathrm{CH}_{4}$ oxidation and uptake activity by soil bacteria. ${ }^{55}$

However, some studies has been indicated that application of biochar did not affect soil $\mathrm{CH}_{4}$ emissions, ${ }^{31}$ had no significant effect on the $\mathrm{CH}_{4}$ emissions from a deciduous forest soil, ${ }^{56,57}$ no significant difference in $\mathrm{CH}_{4}$ flux between biochar-treated and control soils in a temperate hardwood forest,$^{31}$ and application of it with rate of (24 tha ${ }^{-1}$ ) did not affect $\mathrm{CH}_{4}$ emission in a sub-tropic acidic forest soil ${ }^{22}$ (Table 2). 
Contrary to these findings, Mitchell et al. ${ }^{49}$ reported that the application of sugar maple biochar $\left(5,10\right.$, and $\left.20 \mathrm{t} \mathrm{ha}^{-1}\right)$ significantly increased soil $\mathrm{CO}_{2}$ emissions in a temperate forest soil. Johnson et al. ${ }^{50}$ also reported increased $\mathrm{CO}_{2}$ emissions from a biochar-amended soil compared to the emissions from the untreated control soil. Hawthorne et al. ${ }^{58}$ also reported significantly higher $\mathrm{CO}_{2}$ fluxes (increased by $191 \%$ ) from soil treated with $10 \%$ biochar compared to the emissions from the same soil treated with $1 \%$ biochar. According to Yongfu et al. ${ }^{59}$ mechanisms underlying $\mathrm{CH}_{4}$ flux from soils after biochar application and especially concerning with microbial metabolism were complicated.

Soil $\mathrm{N}_{2} \mathrm{O}$ emission: Evidence concerning the potential for reduced $\mathrm{N}_{2} \mathrm{O}$ emissions as a result of biochar application in dry land soils has been confirmed in many farmland soils. ${ }^{60}$ Sun et al. ${ }^{47}$ found that the application of biochar with the rate of 30 tha $^{-1}$ significantly decreased cumulative $\mathrm{N}_{2} \mathrm{O}$ emission in forest soil by $25.5 \%$. Likewise, Xiao et al. ${ }^{54}$ reported that biochar application with rate of $5 \mathrm{tha}^{-1}$ in the forest soil reduced annual average flux and annual cumulative total soil $\mathrm{N}_{2} \mathrm{O}$ emissions by 27.4 and $20.5 \%$, respectively when compared to that of the untreated. Rondon et al. ${ }^{61}$ also reported that $50 \%$ and $80 \%$ reduction of $\mathrm{N}_{2} \mathrm{O}$ emissions under soybean and grass systems, respectively due to biochar addition.
However, application of biochar with rate of $\left(5\right.$ tha $\left.^{-1}\right)$ in a temperate hardwood forest did not change soil $\mathrm{N}_{2} \mathrm{O}$ emission. ${ }^{31} \mathrm{On}$ other hand, Clough et al. ${ }^{62}$ reported that $\mathrm{N}_{2} \mathrm{O}$ emissions increased after the application of biochar to the soil. Similarly, Hawthorne et al. ${ }^{58}$ reported that amending of $10 \%$ biochar in a forest soil significantly increased $\mathrm{N}_{2} \mathrm{O}$ emissions. Thus, why and how biochar addition on soil increased $\mathrm{N}_{2} \mathrm{O}$ emission processes was quite complicated. ${ }^{59}$

Soil contamination: According to Jones et al. ${ }^{63}$ application of biochar with rate of $\left(25\right.$ tha $\left.^{-1}\right)$ was the most effective for soil contaminant adsorption, suppressed biodegradation and leaching of contaminants into groundwater. $\mathrm{Yu}$ et al. ${ }^{64}$ also reported that biochar produced from woodchips and cotton straw which pyrolyzed at $850^{\circ} \mathrm{C}$ resulted a remarkable decrease in the uptake of pesticides by the plants grown in contaminated soils. In general, the biochar produced at higher temperatures exhibit higher sorption efficiency for organic contaminant remediation in soil.

Unlike organic contaminants, heavy metals are non-biodegradable and their bioavailability makes them highly toxic to living organisms. ${ }^{26}$ But, biochar has been mostly amended to synchronize those toxic heavy metals in contaminated soil ${ }^{65}$ as indicated in (Figure 3 ) and (Table 3). ${ }^{66-70}$

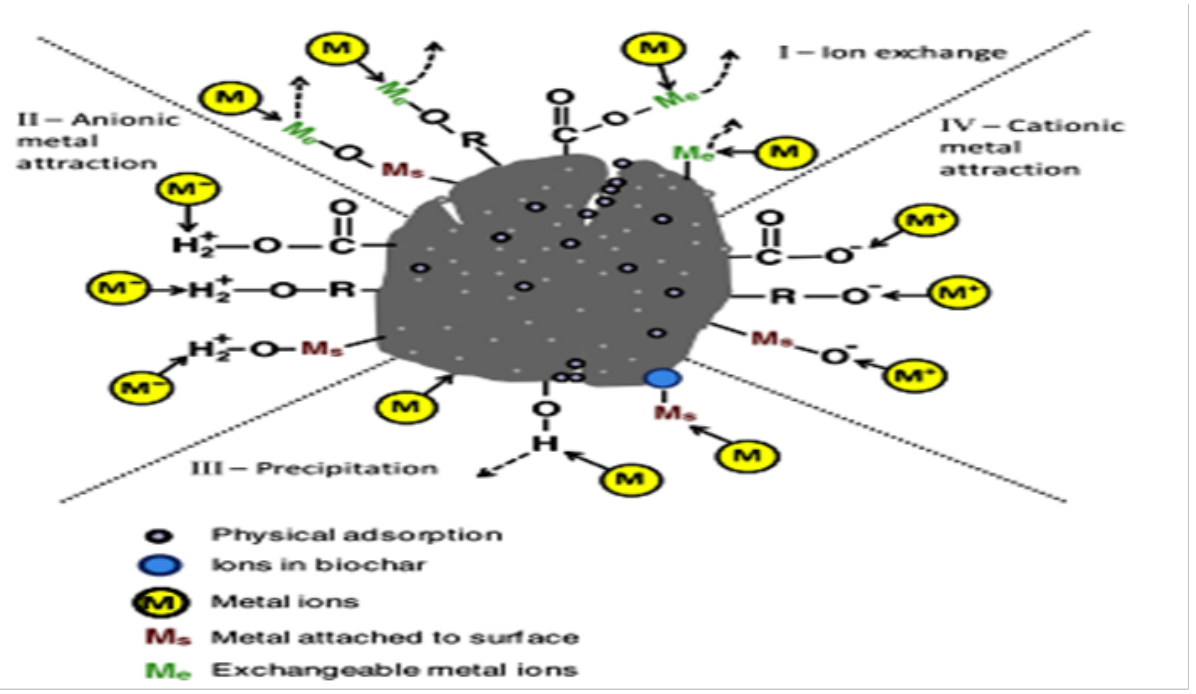

Figure 3 Mechanisms of biochar interaction with inorganic contaminants. Circles in the biochar particle show physical adsorption, l-ion exchange between target metal and exchangeable metal in the biochar, II-electrostatic attraction of an ionic metal, III- precipitation of target metals and IV-electrostatic attraction of cationic metal (Source: Ahmed et al., 2014).

Table 3 Effect of biochar application in contaminated soil

\begin{tabular}{llll}
\hline Contaminants & Biochar type & Matrix & Effect \\
\hline Chloropyrfos \& carbofuran & Woodchips $(450 \& 850)$ & soil & Adsorption due to high surface area and nano-porosity \\
Pentachlorophenol & Bamboo $\left(600^{\circ} \mathrm{C}\right)$ & soil & Reduced leaching due to diffusion and partition \\
Pentachlorophenol & Rice straw & soil & Adsorption due to high surface area and micro-porosity \\
Simazine & Hardwood $\left(450\right.$ and $\left.600^{\circ} \mathrm{C}\right)$ & soil & Sorption due to abundance of micro-pores \\
Arsenic & Hard wood $\left(400^{\circ} \mathrm{C}\right)$ & soil & Mobilization due to enhanced $\mathrm{pH}$ \\
Cadmium and zinc & Hard wood & soil & Immobilization due to enhanced $\mathrm{pH}$ \\
Lead & Oak wood $\left(400^{\circ} \mathrm{C}\right)$ & soil & Immobilization by rise in soil $\mathrm{pH}$ and adsorption onto \\
\hline
\end{tabular}

Source cited in Ahmad et al. ${ }^{66}$ 


\section{Conclusion and way forwards}

Biochar is most eco-friendly technology that should be used for soil fertility improvement and climate change mitigation. But:

a. The effects of biochar addition on soil $\mathrm{N}_{2} \mathrm{O}$ emission processes and the mechanisms involved require further investigations

b. $\mathrm{CH}_{4}$ flux from soils after biochar application especially concerning microbial metabolism require further investigations

\section{Acknowledgments}

None.

\section{Conflicts of interests}

Authors declare no conflict of interest exists.

\section{References}

1. Tilahun Amede, Takele belachew and endrias geta. Reversing the degradation of arable land in the Ethiopian highlands. No 23. 2001.

2. Jones CA, Sands RD. Impact of agricultural productivity gains on greenhouse gas emissions: A global analysis. American journal of agricultural economics. 2013;95(5):1309-1316.

3. International biochar Initiative IB. Standardized product definition and product testing guidelines for biochar that is used in soil. IBI biochar Stand. 2012.

4. Shackley S, Carter S, Knowles T, et al. Sustainable gasification-biochar systems? A case-study ofrice-husk gasification in Cambodia, Part 1: Context, chemical properties,environmental and health and safety issues. Energy Policy. 2012;42:49-58.

5. Lim JS, Manan ZA, Alwi SRW, et al. A review on utilization of biomass from rice industry as a source of renewable energy. Renewable and sustainable energy reviews. 2012;16(5):3084-3094.

6. Lim JS, Manan ZA, Alwi SRW, et al. A review on utilization of biomass from rice industry as a source of renewable energy. Renewable and sustainable energy reviews. 2012;16(5):3084-3094.

7. Awad YM, Blagodatskaya E, Ok YS, et al. Effects of polyacrylamide, biopolymer and biochar on the decomposition of 14C labelled maize residues and on their stabilization in soil aggregates. European journal of soil science. 2013;64(4):488-499.

8. Kammann CI, Schmidt HP, Messerschmidt N, et al. Plant growth improvement mediated by nitrate capture in co-composted biochar. Scientific reports. 2015;5:11080.

9. Sohi S, Lopez-Capel E, Krull E, et al. Biochar, climate change and soil: A review to guide future research. CSIRO Land and Water Science Report. 2009;5(09):17-31.

10. Lehmann J, Skjemstad J, Sohi S, et al. Australian climate-carbon cycle feed-back reduced by soil black carbon. Nature Geoscience. 2008;1(12):832.

11. Singh BP, Cowie AL, Smernik RJ.. Biochar carbon stability in a clayey soil as a function of feedstock and pyrolysis temperature. Environmental science \& technology. 2012;46(21):11770-11778.

12. Zwieten L, Singh B, Joseph S, et al. Biochar and emissions of non-CO2 greenhouse gases from soil. Biochar for environmental management: science and technology. 2009;1:227-250.

13. Woolf D, Amonette JE, Street-Perrott FA, et al. Sustainable biochar to mitigate global climate change. Nature communications. 2010;(1):56.
14. Ahmad M, Rajapaksha AU, Lim JE, et al. Biochar as a sorbent for contaminant management in soil and water: a review. Chemosphere. 2014;99:19-33.

15. Gul S, Whalen JK, Thomas BW, et al. Physico-chemical properties and microbial responses in biochar-amended soils: mechanisms and future directions. Agriculture, Ecosystems \& Environment. 2015;206:46-59.

16. Lehmann J. Bio-energy in the black. Frontiers in Ecology and the Environment. 2007;5(7):381-387.

17. Luo Y, Yu ZY, Zhang KL, et al. The properties and functions of biochars in forest ecosystems. J Soils Sediments. 2016;16:2005-2020

18. Manyà JJ. Pyrolysis for biochar purposes: a review to establish current knowledge gaps and research needs. Environmental science \& technology. 2012;46(15):7939-7954.

19. Hseu ZY, Jien SH, Chien WH, et al. Impacts of biochar on physical properties and erosion potential of a mudstone slope land soil. The Scientific World Journal. 2014.

20. Gamage DV, Mapa RB, Dharmakeerthi RS, et al. Effect of rice-husk biochar on selected soil properties in tropical Alfisols. Soil Research. 2016;54(3):302-310.

21. Prober SM, Stol J, Piper M, et al. Enhancing soil biophysical condition for climate-resilient restoration in mesic woodlands. Ecological engineering. 2014;71:246--255.

22. Lin ZB, Liu Q, Liu G, et al. Effects of different biochars on Pinus elliottii growth, $\mathrm{N}$ use efficiency, soil $\mathrm{N} 2 \mathrm{O}$ and $\mathrm{CH} 4$ emissions and $\mathrm{C}$ storage in a subtropical area of China. Pedosphere. 2017;27(2):248 261.

23. Uzoma KC, Inoue M, Andry H, et al. Influence of biochar application on sandy soil hydraulic properties and nutrient retention. $J$ Food Agric Environ. 2011;9(3-4):1137-1143.

24. Dan T, Zhong-Yi, Mang-Mang G, et al. Experimental study of influence of biochar on different texture soil hydraulic characteristic parameters and moisture holding properties. Polish Journal of Environmental Studies. 2015;24(3).

25. Lu SG, Sun FF, Zong YT. Effect of rice husk biochar and coal fly ash on some physical properties of expansive clayey soil (Vertisol). Catena. 2014;114:37-44.

26. Zhang X, Wang $\mathrm{H}, \mathrm{He} \mathrm{L}$, et al. Using biochar for remediation of soils contaminated with heavy metals and organic pollutants. Environ Sci Pollut Res. 2013 Dec;20(12):8472-8483.

27. Ouyang L, Wang F, Tang J, et al. Effects of biochar amendment on soil aggregates and hydraulic properties. Journal of soil science and plant nutrition. 2013;13(4):991-1002.

28. Rhoades CC, Minatre KL, Pierson DN, et al. Examining the potential of forest residue-based amendments for post-wildfire rehabilitation in Colorado, USA. Scientifica. 2017.

29. Yuan JH, Xu RK, Qian W, et al. Comparison of the ameliorating effects on an acidic ultisol between four crop straws and their biochars. Journal of Soils and Sediments. 2011;11(5):741-750.

30. Dai ZM, Zhang XJ, Tang C, et al. Potential role of biochars in decreasing soil acidification. Sci Total Environ. 2017;581-582:601-611.

31. Sackett TE, Basiliko N, Noyce GL, et al. Soil and greenhouse gas responses to biochar additions in a temperate hardwood forest. $G c b$ Bioenergy. 2015;7(5):1062-1074.

32. Laird DA, Fleming P, Davis DD, et al. Impact of biochar amendments on the quality of a typical Midwestern agricultural soil. Geoderma. 2010;158(3-4):443-449. 
33. Wang Z, Li Y, Chang S, et al. Contrasting effects of bamboo leaf and its biochar on soil $\mathrm{CO} 2$ flux and labile organic carbon in an intensively managed Chinese chestnut plantation. Biology and fertility of soils. 2014;50(7):1109-1119.

34. Lorenz K, Lal R. Biochar application to soil for climate change mitigation by soil organic carbon sequestration. Journal of Plant Nutrition and Soil Science. 2014;177(5):651-670.

35. Biederman LA, Harpole WS. Biochar and its effects on plant productivity and nutrient cycling: a meta $\square$ analysis. $G C B$ bioenergy. 2013; 5(2):202-214

36. Page-Dumroese DS, Coleman MD, Thomas SC, et al.Opportunities and uses of biochar on forest sites in North America. Biochar: A Regional Supply Chain Approach in View of Mitigating Climate Change. 2016;15:315-336.

37. Gundale MJ, Nilsson MC, Pluchon N, et al. The effect of biochar management on soil and plant community properties in a boreal forest. Gcb Bioenergy. 2016;8(4):777-789.

38. Kloss S, Zehetner F, Oburger E, et al. Trace element concentrations in leachates and mustard plant tissue (Sinapis alba L.) after biochar application to temperate soils. Science of the Total Environment. 2016;481:498-508.

39. Lehmann J, da Silva JP, Steiner C, et al. Nutrient availability and leaching in an archaeological Anthrosol and a Ferralsol of the Central Amazon basin: fertilizer, manure and charcoal amendments. Plant and soil. 2003;249(2):343-357.

40. Glaser B, Lehmann J, Zech W. Ameliorating physical and chemical properties of highly weathered soils in the tropics with charcoal a review. Biology and fertility of soils. 2002;35(4):219-230.

41. Beck DP. Suitability of charcoal-amended mineral soil as carrier for rhizobium inoculants. Soil Biol Biochem. 1991;23:41-44.

42. Saranya K, Kumutha K, Krishnan PS. Influence of biochar and Azospirillum application on the growth of maize. Madras Agric J. 2011;98:158-164.

43. Tripti, Kumar A, Usmani Z, Kumar V. Biochar and fyash inoculated with plant growth promoting Rhizobacteria act as potential biofertilizer for luxuriant growth and yield of tomato plant. J Environ Manag. 2017;190:20-27.

44. Głodowska M, Husk B, Schwinghamer T, et al. Biochar is a growthpromoting alternative to peat moss for the inoculation of corn with a pseudomonad. Agron Sustain Dev. 2016;36:21.

45. Egamberdieva D, Wirth S, Behrendt U, et al. Biochar treatment resulted in a combined effect on soybean growth promotion and a shift in plant growth promoting rhizobacteria. Front Microbiol. 2016;7:209.

46. Chen J, Liu X, Zheng J, et al. Biochar soil amendment increased bacterial but decreased fungal gene abundance with shifts in community structure in a slightly acid rice paddy from Southwest China. Applied Soil Ecology. 2013;71:33-44.

47. Sun L, Li L, Chen Z, et al. Combined effects of nitrogen deposition and biochar application on emissions of $\mathrm{N} 2 \mathrm{O}, \mathrm{CO} 2$ and $\mathrm{NH} 4$ from agricultural and forest soils. Soil science and plant nutrition. 2014;60(2):254-265.

48. Zhou G, Zhou X, Zhang T, et al. Biochar increased soil respiration in temperate forests but had no effects in subtropical forests. Forest Ecology and Management. 2017;405:339-349.

49. Mitchell PJ, Simpson AJ, Soong R, et al. Shifts in microbial community and water-extractable organic matter composition with biochar amendment in a temperate forest soil. Soil Biology and Biochemistry. 2015;81:244-254.
50. Johnson MS, Webster C, Jassal RS, et al. Biochar influences on soil $\mathrm{CO} 2$ and $\mathrm{CH} 4$ fluxes in response to wetting and drying cycles for a forest soil. Scientific reports. 2017;7(1):6780.

51. Woolf D, Lehmann J. Modeling the long-term response to positive and negative priming of soil organic carbon by black carbon. Biogeochemistry. 2012;111(1):83-95

52. Liu YX, Yang $\mathrm{M}, \mathrm{Wu} \mathrm{YM}$, et al. Reducing $\mathrm{CH} 4$ and $\mathrm{CO} 2$ emissions from water-logged paddy soil with biochar. $J$ Soils Sediments. 2011;11:930-939.

53. Yu L, Tang J, Zhang R, et al. Effect of biochar application on soilmethane emission at different soil moisture levels. Biol Fertil Soils. 2013;49:119-128.

54. YH, Li YF, Wang ZL, et al. Effects of bamboo leaves and their biochar additions on soil $\mathrm{N} 2 \mathrm{O}$ flux in a chinese chestnut forest. J Plant Nutr Fert. 2016;22:697-706.

55. Brassard P, Godbout S, Raghavan V. Soil biochar amendment as a climate change mitigation tool: Key parameters and mechanisms involved. J Environ Manag. 2016;181:484-497.

56. Malghani S, Gleixner G, Trumbore SE. Chars produced by slow pyrolysis and hydrothermal carbonization vary in carbon sequestration potential and greenhouse gases emissions. Soil Biol Bioche. 2013;62:137-146.

57. Li ZG, Gu CM, Zhang RH, et al. The benefic effect induced by biochar on soil erosion and nutrient loss of slopping land under natural rainfall conditions in central China. Agricultural water management. 2017:185:145-150.

58. Hawthorne I, Johnson MS, Jassal RS, et al. Application of biochar and nitrogen influences fluxes of $\mathrm{CO} 2, \mathrm{CH} 4$ and $\mathrm{N} 2 \mathrm{O}$ in a forest soil. Journal of environmental management. 2017;192:203-214.

59. Yongfu Li, Shuaidong $\mathrm{Hu}$, Junhui Chen1, et al. Effects of biochar application in forest ecosystems on soil properties and greenhouse gas emissions: a review, Journal of Soils and Sediments. 20148;18:546563.

60. He L, Fan S, Müller K, et al. Biochar reduces the bioavailability of di(2-ethylhexyl) phthalate in soil. Chemosphere. 2016;142:24-27.

61. Rondon M, Ramirez JA, Lehmann J. Charcoal additions reduce net emissions of greenhouse gases to the atmosphere. 2005;208: 1-24.

62. Clough TJ, Bertram JE, Ray JL, et al. Un-weathered wood biochar impact on nitrous oxide emissions from a bovine-urine-amended pasture soil. Soil Science Society of America Journal. 2010;74(3):852860 .

63. Jones DL, Murphy DV, Khalid M, et al. Short-term biochar-induced increase in soil $\mathrm{CO} 2$ release is both biotically and abiotically mediated. Soil Biol Biochem. 2011;43:1723-1731.

64. Yu XY, Ying GG, Kookana RS, et al. Reduced plant uptake of pesticides with biochar additions to soil. Chemosphere. 2009;76:665-671.

65. Park JH, Choppala GK, Bolan NS, et al. Biochar reduces the bioavailability and phytotoxicity of heavy metals. Plant Soil. 2011;348: 439-451.

66. Ahmad M, Lee SS, Dou X, et al. Effects of pyrolysis temperature on soybean stover- and peanut shell-derived biochar properties and TCE adsorption in water. Bioresour Technol. 2012;118:536-544.

67. Beesley L, Jiménez, EM, Eyles JLG. Effects of biochar and green waste compost amendments on mobility, bioavailability and toxicity of inorganic and organic contaminants in a multi-element polluted soil. Environ. Pollut. 2010;158:2282-2287. 
68. Cantrell KB, Hunt PG, Uchimiya M, et al. Impact of pyrolysis temperature and manure source on physicochemical characteristics of biochar. Bioresour Technol. 2012;107:419-428.

69. Eyob and Dereje. Characterization of biochar produced from different feedstock. In-press. 2018.
70. He Y, Zhou X, Jiang L, et al. Effects of biochar application on soil greenhouse gas fluxes: a meta-analysis. Gcb Bioenergy. 2010;9(4):743755 . 